\title{
EFFECT OF PLANT $\times$ ROW SPACING ON TWO VARIETIES OF BORO RICE
}

\author{
M.K. Hasan ${ }^{1}$, M.D. Hossain ${ }^{1}$, M.R. Uddin ${ }^{1}$, M.S. Kobir ${ }^{2^{*}}$ and M.H. Kabir ${ }^{1}$ \\ ${ }^{1}$ Department of Agronomy, Bangladesh Agricultural University, Mymensingh, Bangladesh \\ ${ }^{2}$ Bangladesh Agricultural Research Institute, Gazipur, Bangladesh
}

\begin{abstract}
A field study was undertaken at Bangladesh Agricultural University, Mymensingh during the season November 2017 to April 2018 to evaluate the effects of plant $\times$ row spacings on yield and yield contributing traits of two Boro rice varieties. Two rice varieties viz., BINA dhan-10 and BRRI dhan28 were sown in five plant spacings viz. $25 \mathrm{~cm} \times 15 \mathrm{~cm}, 25 \mathrm{~cm} \times 25$ $\mathrm{cm}, 30 \mathrm{~cm} \times 30 \mathrm{~cm}, 35 \mathrm{~cm} \times 35 \mathrm{~cm}, 40 \mathrm{~cm} \times 40 \mathrm{~cm}$ in randomized completely block design with factorial fashion with three replications. Growth performances, yield contributing characters and yield were significantly influenced by varieties and plant spacings. The highest grain yield $\left(8.75 \mathrm{tha}^{-1}\right)$, straw yield $\left(11.56 \mathrm{t} \mathrm{ha}^{-1}\right)$, biological yield $\left(20.31 \mathrm{t} \mathrm{ha}^{-1}\right)$ and harvest index $(43.05 \%)$ were obtained from the variety BINA dhan10 sown at planting spacing of $25 \mathrm{~cm} \times 15 \mathrm{~cm}$. More number of total tillers hill ${ }^{-1}(14.75)$ and number of effective tiller hill $^{-1}$ (12.87) were recorded from the variety BINA dhan-10 sown at planting spacing $40 \mathrm{~cm}$ $\times 40 \mathrm{~cm}$. Based on the present study it is suggested that BINA dhan-10 may be grown under $25 \mathrm{~cm} \times 15 \mathrm{~cm}$ in order to get maximum grain yield for Boro rice cultivation.
\end{abstract}

Keywords: Boro rice, BINA dhan-10, BRRI dhan28, Biological yield, Grain yield, Growth characters

\section{INTRODUCTION}

Rice (Oryza sativa L.) belonging to Gramineae family is a staple food for about three billion people around the world (Koireng et al., 2019). Bangladesh is one of the leading rice producing country in the world, ranking fourth in terms of total rice production after China, India and Indonesia (Statista, 2019). In Bangladesh, rice is grown mainly in three cropping seasons namely Aus, Aman and Boro. Among the three rice growing season, $48.82 \%$ of total rice production was grown in Boro season in 2018-19 fiscal year (BBS, 2019) with total production of 37.36 million metric ton

\footnotetext{
* Corresponding Author: Shahriar1302027@gmail.com
} 
from 11.67 million hectares where average rice yield was 3.2 metric ton per hectare (AIS, 2020).While Boro rice is the largest crop in Bangladesh in terms of production i.e. about 20.38 million metric ton Boro rice produced from 4.09 million hectares land with an average yield of 4.15 metric ton per hectare (AIS, 2020). Though being staple food and having favorable agro-climatic condition, its expansion is limited due to shortage of land and to meet the need of increasing population. Therefore, attempts must be taken for vertical expansion of rice cultivation in Bangladesh like high yielding variety and different cultural practices with modern production technology. Keeping in view, the yield of Boro rice can be increased by maintaining proper spacing with high yielding variety.

Facilitating easy inter-cultural operation and efficiently and conveniently herbicide application for weed control is a beneficial part of optimum spacing maintaining in crop production (Koireng et al., 2019). Likewise, for getting maximum light interception, average light utilization efficiency and to maximize light distribution in crop canopy, proper planting geometry is important. These parameters indirectly affect the yield of crops (Hussain et al., 2003). The planting density which is determined by row to row and plant to plant distances has a direct effect on the yield of rice. Furthermore, grain may be reduced in narrow spacing as compared to optimum spacing due to increased competition for nutrient and moisture (Das and Yaduraju, 2011).

Another important factor is rice cultivars which are generally selected for higher grain yields (Kumar et al., 2013). However, success of any crop production depends on using of appropriate and location-specific varieties, additionally improved cultural practices may be taken into consideration. Planting spacing and variety are of lead important (Eissa et al., 1995), but all the genotypes do not perform well in the same planting spacing. Optimum planting spacing vary greatly among climatic conditions, areas, soil and varieties (Darwinkel et al., 1977).

Keeping in view the above facts, the present study was undertaken to find out the effect of different spacing and genotypes on yield of Boro rice and to find out the interactive effects of planting density and genotypes on yield performances of Boro rice, if any.

\section{MATERIALS AND METHODS}

The study was conducted at the Field Bangladesh Agricultural University, Mymensingh, during the season 2017-18. The research field is belonged to the agroecological region of the Old Brahmaputra Floodplain (AEZ-9) (BBS, 2019) having sub-tropical monsoon climate featured by heavy rainfall during April-October and scarce rainfall during October- March.

Two rice varieties viz. BINA dhan-10 and BRRI dhan 28 were sown in five spacing viz., $25 \mathrm{~cm} \times 15 \mathrm{~cm}, 25 \mathrm{~cm} \times 25 \mathrm{~cm}, 30 \mathrm{~cm} \times 30 \mathrm{~cm}, 35 \mathrm{~cm} \times 35 \mathrm{~cm}, 40 \mathrm{~cm} \times 40 \mathrm{~cm}$. The experiment was laid out in a randomized completely block design in factorial fashion with three replications. The size of the plot was $4.0 \mathrm{~m} \times 2.5 \mathrm{~m}$. 
Seeds of both varieties were separately immersed in a bucket of water for 24 hours. Thereafter, the sprouted seeds of different varieties were sown uniformly on wellprepared nurseries on 15 December, 2017. The experimental land was prepared with the help of tractor drawn plough. The land was puddled thoroughly by ploughing and cross ploughing. The lands were finally prepared, and the plots were laid out on 12 January, 2018. The experimental plots were fertilized with urea, triple super phosphate (TSP) muriate of potash (MOP), gypsum and zinc Sulphate as per recommendation prescribed for those varieties (Table1).

Table 1. Fertilizer doses for different rice varieties (BINA, 2021; BRRI, 2021)

\begin{tabular}{lccccc}
\hline Variety & $\begin{array}{c}\text { Urea } \\
\left(\mathrm{kg} \mathrm{ha}^{-1}\right)\end{array}$ & $\begin{array}{c}\text { TSP } \\
\left(\mathrm{kg} \mathrm{ha}^{-1}\right)\end{array}$ & $\begin{array}{c}\text { MoP } \\
\left(\mathrm{kg} \mathrm{ha}^{-1}\right)\end{array}$ & $\begin{array}{c}\text { Gypsum }(\mathrm{kg} \\
\left.\mathrm{ha}^{-1}\right)\end{array}$ & $\begin{array}{c}\text { Zinc sulphate } \\
\left(\mathrm{kg} \mathrm{ha}^{-1}\right)\end{array}$ \\
\hline BINA dhan-10 & 160 & 130 & 60 & 85 & 15 \\
BRRI dhan28 & 150 & 100 & 70 & 60 & 12 \\
\hline
\end{tabular}

Seedlings of both varieties were transplanted on 15 January, 2018 maintaining five spacings as per treatment. Different intercultural operations like gap filling, weeding, irrigation and drainage were done when needed. Harvesting was done on proper harvest maturity. An area of one $\mathrm{m}^{2}$ was selected in the middle portion of each plot to record the yield of grain and straw. The yield of grains was adjusted at $14 \%$ moisture content and converted to ton per hectare.

Five hills in each plot were tagged for recording data on plant height $(\mathrm{cm})$, no. of total tiller per hill, total dry weight per hill in 30 days after transplanting (DAT), 50 DAT and in 70 DAT. At harvest, data on plant height, number of effective tillers hill ${ }^{-1}$, panicle length, number of grains per panicle, number of sterile spikelet panicle ${ }^{-1}$, 1000-grain weight, grain yield $\left(\mathrm{t} \mathrm{ha}^{-1}\right)$, straw yield $\left(\mathrm{t} \mathrm{ha}^{-1}\right)$ were collected and then biological yield $\left(\mathrm{t} \mathrm{ha}^{-1}\right)$ was calculated. Analysis of variance was done by a statistical software M-STATC and mean separation was done by Duncan's Multiple Range Test Gomez and Gomez, 1984. Correlation-co-efficient and regression equation was measured by using Microsoft excel program.

\section{RESULTS AND DISCUSSION}

\section{Effect on growth parameters}

The highest plant height $32.18 \mathrm{~cm}, 55.01 \mathrm{~cm}$ and $80.37 \mathrm{~cm}$ was found by BINA dhan-10 at 30 DAT, 50 DAT and 70 DAT, respectively. The lowest plant height $30.06 \mathrm{~cm}, 52.11 \mathrm{~cm}$ and $77.48 \mathrm{~cm}$ was found by BRRI dhan28 at 30 DAT, 50 DAT and 70 DAT, respectively. The highest plant height $33.96 \mathrm{~cm}, 56.54 \mathrm{~cm}$ and 84.84 $\mathrm{cm}$ was found by spacing $25 \mathrm{~cm} \times 15 \mathrm{~cm}$ at 30 DAT, 50 DAT and 70 DAT, respectively. The lowest plant height $29.02 \mathrm{~cm}, 49.39 \mathrm{~cm}$ and $73.54 \mathrm{~cm}$ was found by spacing $40 \mathrm{~cm} \mathrm{X} 40 \mathrm{~cm}$ at 30 DAT, 50 DAT and 70 DAT, respectively. Interaction between variety and planting geometry showed non-significant variation for plant height (Fig. 1). 


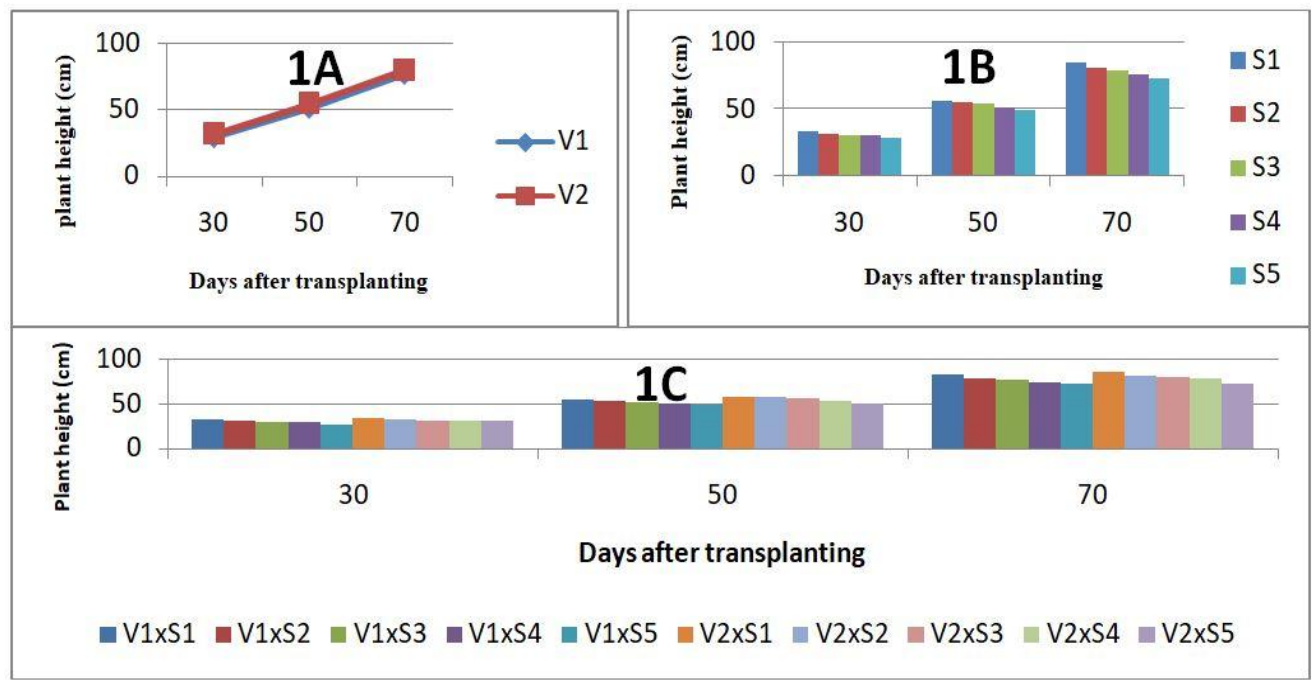

Figure 1. A: effect of variety on plant height $(\mathrm{cm})$ at different days after transplanting, B: effect of planting geometry on plant height $(\mathrm{cm})$ at different days after transplanting, C: Interaction effect of variety and planting geometry on plant height $(\mathrm{cm})$ at different days after transplanting

$\left(\mathrm{V}_{1}=\right.$ BRRI dhan28, $\mathrm{V}_{2}=$ BINA dhan $-10, \mathrm{~S}_{1}=25 \mathrm{~cm} \times 15 \mathrm{~cm}, \mathrm{~S}_{2}=25 \mathrm{~cm} \mathrm{x} 25 \mathrm{~cm}$, $\left.\mathrm{S}_{3}=30 \mathrm{~cm} \times 30 \mathrm{~cm}, \mathrm{~S}_{4}=35 \mathrm{~cm} \times 35 \mathrm{~cm}, \mathrm{~S}_{5}=40 \mathrm{~cm} \times 40 \mathrm{~cm}\right)$

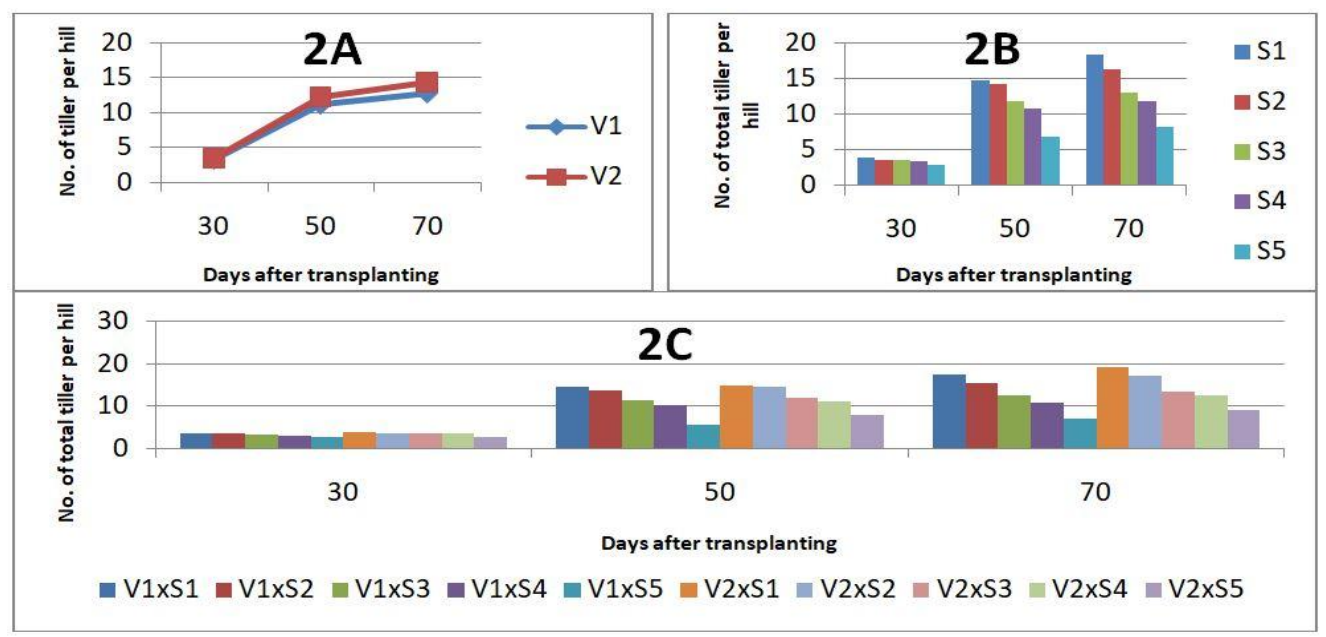

Figure 2. A: effect of variety on no. of total tiller per hill at different days after transplanting, B: effect of planting geometry on no. of total tiller per hill at different days after transplanting, C: Interaction effect of variety and planting geometry on no. of total tiller per hill at different days after transplanting

$\left(\mathrm{V}_{1}=\right.$ BRRI dhan28, $\mathrm{V}_{2}=$ BINA dhan $-10, \mathrm{~S}_{1}=25 \mathrm{~cm} \times 15 \mathrm{~cm}, \mathrm{~S}_{2}=25 \mathrm{~cm} \times 25 \mathrm{~cm}$, $\left.\mathrm{S}_{3}=30 \mathrm{~cm} \times 30 \mathrm{~cm}, \mathrm{~S}_{4}=35 \mathrm{~cm} \times 35 \mathrm{~cm}, \mathrm{~S}_{5}=40 \mathrm{~cm} \times 40 \mathrm{~cm}\right)$ 
The highest no. of total tiller per hill 3.58, 12.25 and 14.42 was found by BINA dhan-10 at 30 DAT, 50 DAT and 70 DAT, respectively. The lowest no. of total tiller per hill 3.43, 11.24 and 12.84 was found by BRRI dhan28 at 30 DAT, 50 DAT and 70 DAT, respectively. The highest no. of total tiller per hill $3.87,14.88$ and 18.50 was found by spacing $40 \mathrm{~cm} \times 40 \mathrm{~cm}$ at 30 DAT, 50 DAT and 70 DAT, respectively. The lowest no. of total tiller per hill 3.00, 6.90 and 8.29 was found by spacing $25 \mathrm{~cm} \times 15 \mathrm{~cm}$ at 30 DAT, 50 DAT and 70 DAT, respectively. The highest no. of total tiller per hill 4.00, 15.00 and 19.38 was found by interaction effect of BINA dhan- 10 and $40 \mathrm{~cm} \times 40 \mathrm{~cm}$ spacing at 30 DAT, 50 DAT and 70 DAT, respectively. The lowest no. of total tiller per hill 3.00, 5.67 and 7.25 was found by interaction effect of BRRI dhan 28 and $25 \mathrm{~cm} \times 15 \mathrm{~cm}$ spacing at 30 DAT, 50 DAT and 70 DAT, respectively (Fig. 2).

The highest total dry weight per hill 0.680, 6.20 and 11.11 was found by BINA dhan-10 at 30 DAT, 50 DAT and 70 DAT, respectively. The lowest total dry weight per hill 0.617, 5.83 and 10.35 was found by BRRI dhan28 at 30 DAT, 50 DAT and 70 DAT, respectively. The highest total dry weight per hill $0.752,7.75$ and 12.73 was found by spacing $40 \mathrm{~cm} \times 40 \mathrm{~cm}$ at 30 DAT, 50 DAT and 70 DAT, respectively. The lowest total dry weight per hill $0.515,4.57$ and 8.92 was found by spacing $25 \mathrm{~cm} \mathrm{X} 15 \mathrm{~cm}$ at 30 DAT, 50 DAT and 70 DAT, respectively. The highest total dry weight per hill 0.780 , 7.90 and 13.43 was found by interaction effect of BINA dhan-10 and $40 \mathrm{~cm} \times 40 \mathrm{~cm}$ spacing at $30 \mathrm{DAT}, 50 \mathrm{DAT}$ and $70 \mathrm{DAT}$, respectively. The lowest total dry weight per hill $0.510,4.20$ and 8.70 was found by interaction effect of BRRI dhan 28 and $25 \mathrm{~cm} \times 15$ $\mathrm{cm}$ spacing at 30 DAT, 50 DAT and 70 DAT, respectively (Fig. 3).

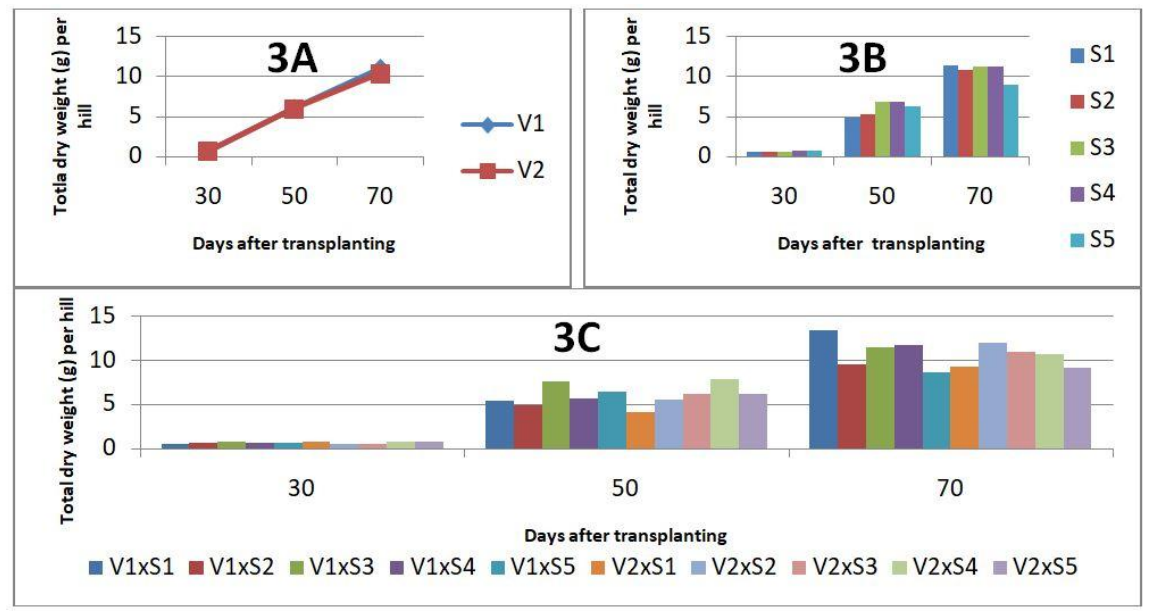

Figure 3. A: effect of variety on total dry weight (g) per hill at different days after transplanting, B: effect of planting geometry on total dry weight $(\mathrm{g})$ per hill at different days after transplanting, C: Interaction effect of variety and planting geometry on total dry weight $(\mathrm{g})$ per hill at different days after transplanting.

$\left(\mathrm{V}_{1}=\right.$ BRRI dhan28, $\mathrm{V}_{2}=$ BINA dhan-10, $\mathrm{S}_{1}=25 \mathrm{~cm} \times 15 \mathrm{~cm}, \mathrm{~S}_{2}=25 \mathrm{~cm} \times 25 \mathrm{~cm}, \mathrm{~S}_{3}=$ $\left.30 \mathrm{~cm} \times 30 \mathrm{~cm}, \mathrm{~S}_{4}=35 \mathrm{~cm} \times 35 \mathrm{~cm}, \mathrm{~S}_{5}=40 \mathrm{~cm} \times 40 \mathrm{~cm}\right)$ 
Several researchers have mentioned that different varieties have different caliber to show its potentiality in regards to plant height, total number of tiller per hill and total dry weight per hill. In the present study BINA dhan-10 showed higher plant height than BRRI dhan28. It might be for it's higher photosynthesis ability and for its different genetic characters (Yang et al., 2001). This result is consonance with the findings of (Bisne et al., 2006; Nizamani et al., 2014 and Suleiman et al., 2014). Similarly differences in tiller number were also observed as different varieties have different genetic makeup. These results are similar to the findings of (Rahman et al., 2010; Mali and Choudhary, 2011). In the present study plant height was found highest in the spacing of $25 \mathrm{~cm} \times 15 \mathrm{~cm}$. In the previous study of (Koireng et al., 2019; Sihag et al., 2010) highest plant height was observed by row spacing of $25 \mathrm{~cm}$ which is more or less similar to our present study. Earlier reports suggested that reported that highest no. of total tiller per square meter was observed when plants were transplanted in $25 \mathrm{~cm}$ row spacing (Koireng et al., 2019; Ali et al., 2016) and in the present study, the highest no. of tiller per hill was observed in $40 \mathrm{~cm} \times 40 \mathrm{~cm}$ spacing. It is may be due to wider spaced plots get higher sun light to make photosynthates. In the current research work, the highest dry weight per hill was observed in $40 \mathrm{~cm} \times 40 \mathrm{~cm}$ spacing. Nevertheless, the higher dry weight per hill was recorded during $30 \mathrm{~cm}$ row spacing (Roy et al., 2014).

\section{Effect on yield and yield contributing characters Effect of varieties}

Different varieties showed significant differences on yield and yield contributing characters of Boro rice except harvest index. The tallest plant height was obtained in BINA dhan-10 and the shortest plant height was recorded in BRRI dhan28 (Table 2).

The highest Number of effective tillers hill ${ }^{-1}$ was obtained in variety BINA dhan-10 and the lowest number of effective tillers hill ${ }^{-1}$ was recorded in variety BRRI dhan 28 (Table 2). The highest panicle length was obtained in the variety BINAdhan-10 and the lowest panicle length was obtained in BRRI dhan28 (Table 2). The highest number of grains panicle ${ }^{-1}$ was obtained in variety BINA dhan-10 and the lowest number of grains panicle ${ }^{-1}$ was obtained in BRRI dhan28 (Table 2). Numerically the highest 1000-grain weight was obtained from the variety BINA dhan-10. The lowest 1000-grain was obtained from the variety BRRI dhan28 (Table 2). It was observed that grain yield was highest in variety BINA dhan-10 and the lowest grain yield was found in the variety BRRI dhan28 (Table 2). The highest straw yield was obtained in variety BINA dhan-10 and the lowest straw yield was obtained from the variety BRRI dhan28 (Table 2).

The differences in plant length might be due to the variation in varietal characters and heredity. Similar trend also reported by (Islam et al., 2012 and Tyeb et al., 2013). Differences in panicle height among genotypes were also stated by (Kabir et al., 2004). Differences in no. of effective tillers per hill among the genotypes were found 
by (Tyeb et al., 2013). Grains per panicle also showed variation among the genotypes reported by (Niu et al., 2001). Grain yield and straw yield also showed variation due to varietal differences. Similar result was also reported by (Akando, 2007; Gawali et al., 2015). They reported that grain and straw yield of wheat was affected by genotypes. In our present study harvest index was showed variation between the genotypes. Similar trend was also reported by (Sultana et al., 2012)

\section{Effect of planting geometry}

Different planting geometry showed significant differences on yield and yield contributing characters of Boro rice except panicle length, no. of grain per panicle. Similar results were also reported (Salma et al., 2017). It suggested that panicle length, grain per panicle had no significant variation by planting geometry. The tallest plant was obtained from the spacing $40 \mathrm{~cm} \times 40 \mathrm{~cm}$ which was statistically identical to plant height gained from spacing $25 \mathrm{~cm} \times 25 \mathrm{~cm}$ and plant height gained from spacing $30 \mathrm{~cm} \times 30 \mathrm{~cm}$. The shortest plant height was observed in spacing 25 $\mathrm{cm} \times 15 \mathrm{~cm}$ which was statistically identical with plant height observed from spacing $35 \mathrm{~cm} \times 35 \mathrm{~cm}$ (Table 2). The highest plant height was attained with the spacing of $25 \mathrm{~cm} \mathrm{X} 20 \mathrm{~cm}$ (Islam et al., 2014). However, other reports (Salma et al., 2017) suggested that the spacing of $25 \mathrm{~cm} \times 15 \mathrm{~cm}$ plant height was maximum which is more or less similar to the present study. The highest number of effective tillers hill ${ }^{-1}$ was obtained from $40 \mathrm{~cm} \times 40 \mathrm{~cm}$ row spacing and the lowest one from the spacing of $25 \mathrm{~cm} \times 15 \mathrm{~cm}$ (Table 2). The highest number of total tillers per hill, highest number of effective tiller per hill was found by spacing $25 \mathrm{~cm} \times 15 \mathrm{~cm}$ (Salma et al., 2017; Islam et al., 2014), which was inverse to the current findings. Numerically the highest 1000-grain weight was recorded from $25 \mathrm{~cm} \times 15 \mathrm{~cm}$ spacing which was identical of spacing $25 \mathrm{~cm} \times 25 \mathrm{~cm}, 30 \mathrm{~cm} \times 30 \mathrm{~cm}$. The lowest 1000 grains weight was recorded from $40 \mathrm{~cm} \times 40 \mathrm{~cm}$ spacing which was statistically identical with 1000-grain weight observed from spacing $35 \mathrm{~cm} \times 35 \mathrm{~cm}$ (Table 2). Thousand seed weight was maximum when $25 \mathrm{~cm} \times 20 \mathrm{~cm}$ spacing was followed (Islam et al., 2014); which is consonance with the current study. The highest grain yield was obtained from the spacing $25 \mathrm{~cm} \times 15 \mathrm{~cm}$ and the lowest one was obtained from the spacing $40 \mathrm{~cm} \times 40 \mathrm{~cm}$ (Table 2). This report is similar to (koireng et al., 2019; Salma et al., 2017; Islam et al., 2014). The highest yield might be due to highest plant height and highest thousand grain weight in spacing $25 \mathrm{~cm} \times 15 \mathrm{~cm}$. The highest straw yield was obtained from the spacing $25 \mathrm{~cm} \times 15 \mathrm{~cm}$ and the lowest one was obtained from the spacing $40 \mathrm{~cm} \times 40 \mathrm{~cm}$ (Table 2). The highest harvest index was obtained from the spacing $25 \mathrm{~cm} \times 15 \mathrm{~cm}$ which was identical with others spacing and the lowest harvest index was at $40 \mathrm{~cm} \times 40 \mathrm{~cm}$ spacing which was identical of spacing $30 \mathrm{~cm} \times 30 \mathrm{~cm}, 35 \mathrm{~cm} \times 35 \mathrm{~cm}$ (Table 2). Similar findings for straw yield and harvest index were reported earlier (Salma et al., 2017; Islam et al., 2014). 
Table 2. Effect of variety, planting geometry and their interaction on yield and yield contributing characters of Boro rice

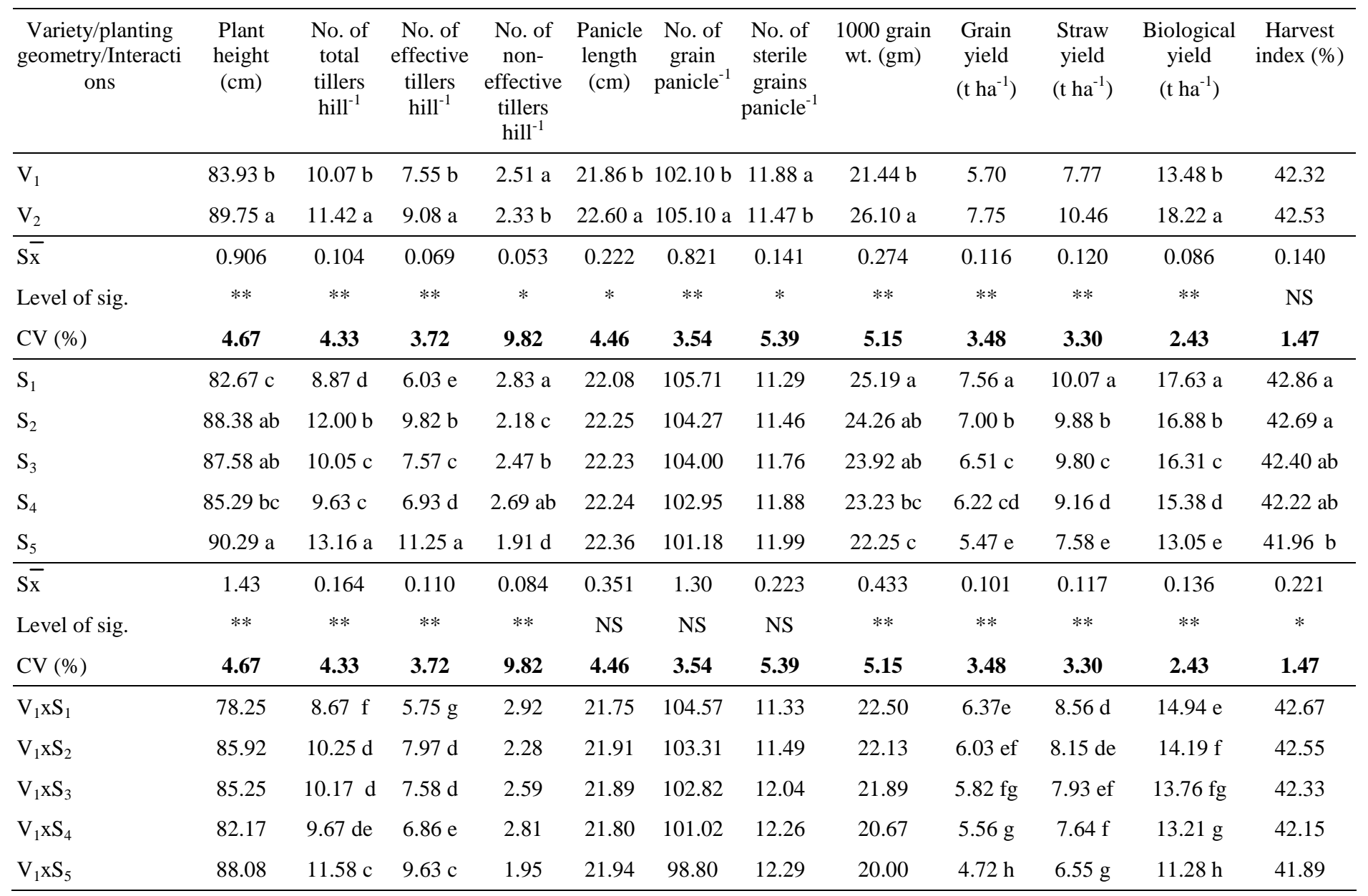




\begin{tabular}{|c|c|c|c|c|c|c|c|c|c|c|c|c|}
\hline $\begin{array}{l}\text { Variety/planting } \\
\text { geometry/Interacti } \\
\text { ons }\end{array}$ & $\begin{array}{l}\text { Plant } \\
\text { height } \\
(\mathrm{cm})\end{array}$ & $\begin{array}{l}\text { No. of } \\
\text { total } \\
\text { tillers } \\
\text { hill- }^{-1}\end{array}$ & $\begin{array}{l}\text { No. of } \\
\text { effective } \\
\text { tillers } \\
\text { hill }^{-1}\end{array}$ & $\begin{array}{c}\text { No. of } \\
\text { non- } \\
\text { effective } \\
\text { tillers } \\
\text { hill }^{-1}\end{array}$ & $\begin{array}{l}\text { Panicle } \\
\text { length } \\
(\mathrm{cm})\end{array}$ & $\begin{array}{l}\text { No. of } \\
\text { grain } \\
\text { panicle }^{-1}\end{array}$ & $\begin{array}{l}\text { No. of } \\
\text { sterile } \\
\text { grains } \\
\text { panicle }^{-1}\end{array}$ & $\begin{array}{c}1000 \text { grain } \\
\text { wt. (gm) }\end{array}$ & $\begin{array}{l}\text { Grain } \\
\text { yield } \\
\left(\mathrm{t} \mathrm{ha}^{-1}\right)\end{array}$ & $\begin{array}{l}\text { Straw } \\
\text { yield } \\
\left(\mathrm{t} \mathrm{ha}^{-1}\right)\end{array}$ & $\begin{array}{l}\text { Biological } \\
\text { yield } \\
\left(\mathrm{t} \mathrm{ha}^{-1}\right)\end{array}$ & $\begin{array}{c}\text { Harvest } \\
\text { index }(\%)\end{array}$ \\
\hline $\mathrm{V}_{2} \mathrm{xS}_{1}$ & 87.08 & 9.08 ef & $6.32 \mathrm{f}$ & 2.75 & 22.40 & 106.85 & 11.24 & 27.88 & $8.75 \mathrm{a}$ & $11.56 \mathrm{a}$ & $20.31 \mathrm{a}$ & 43.05 \\
\hline $\mathrm{V}_{2} \mathrm{xS}_{2}$ & 90.83 & $13.75 \mathrm{~b}$ & $11.67 \mathrm{~b}$ & 2.08 & 22.58 & 105.23 & 11.43 & 26.40 & $8.38 \mathrm{~b}$ & $11.19 \mathrm{ab}$ & $19.58 \mathrm{~b}$ & 42.82 \\
\hline $\mathrm{V}_{2} \mathrm{xS}_{4}$ & 88.42 & $9.60 \mathrm{de}$ & $7.00 \mathrm{e}$ & 2.58 & 22.68 & 104.88 & 11.50 & 25.79 & $7.42 \mathrm{~d}$ & $10.14 \mathrm{c}$ & $17.56 \mathrm{~d}$ & 42.28 \\
\hline $\mathrm{V}_{2} \mathrm{xS}_{5}$ & 92.50 & $14.75 \mathrm{a}$ & $12.87 \mathrm{a}$ & 1.88 & 22.79 & 103.56 & 11.68 & 24.50 & $6.22 \mathrm{e}$ & $8.58 \mathrm{~d}$ & $14.81 \mathrm{e}$ & 42.02 \\
\hline $\bar{S} \bar{x}$ & 2.02 & 0.232 & 0.155 & 0.119 & 0.496 & 1.84 & 0.315 & 0.612 & 0.117 & 0.150 & 0.192 & 0.313 \\
\hline Level of sig. & NS & $* *$ & $* *$ & NS & NS & NS & NS & NS & $* *$ & $* *$ & $* *$ & NS \\
\hline
\end{tabular}

In a column, figures with same letter (s) or without letter do not differ significantly, whereas, figures with dissimilar letter differ significantly, $* *$ $\mathrm{P}<0.01$, * $\mathrm{P}<0.05$, NS = Not significant, $\mathrm{V}_{1}=\mathrm{BRRI}$ dhan28, $\mathrm{V}_{2}=\mathrm{BINA}$ dhan $-10, \mathrm{~S}_{1}=25 \mathrm{~cm} \times 15 \mathrm{~cm}, \mathrm{~S}_{2}=25 \mathrm{~cm} \times 25 \mathrm{~cm}, \mathrm{~S}_{3}=30 \mathrm{~cm} \times 30 \mathrm{~cm}, \mathrm{~S}_{4}=$ $35 \mathrm{~cm} \times 35 \mathrm{~cm}, \mathrm{~S}_{5}=40 \mathrm{~cm} \times 40 \mathrm{~cm}$ 


\section{Interaction effect of variety and planting geometry}

Different interaction between planting geometry and variety showed significant differences on yield and yield contributing characters of Boro rice except plant height, panicle length, no. of grain per panicle, thousand seed weight and harvest index. These results are at per with the previous study (Salma et al., 2017). It revealed that the plant height and harvest index due to interaction of variety and spacing showed non- significant variation. The highest number of effective tillers hill $^{-1}$ was obtained in BINA dhan-10 with the interaction of spacing $40 \mathrm{~cm} \times 40 \mathrm{~cm}$, whereas the lowest number of effective tillers hill ${ }^{-1}$ was obtained in BRRI dhan 28 with the interaction of spacing $25 \mathrm{~cm} \times 15 \mathrm{~cm}$ (Table 2). The highest grain yield was recorded in variety BINA dhan-10 with the spacing $25 \mathrm{~cm} \times 15 \mathrm{~cm}$ on the other hand the lowest grain yield was obtained in BRRI dhan 28 with the interaction of spacing $40 \mathrm{~cm} \times 40 \mathrm{~cm}$ (Table 2). The highest grain yield was found when BR 25 rice variety was cultivated with the spacing of $25 \mathrm{~cm} \times 15 \mathrm{~cm}$ (Salma et al., 2017), which is consonance with the present findings. The highest straw yield was obtained in BINA dhan-10 with the spacing $25 \mathrm{~cm} \times 15 \mathrm{~cm}$ which was statistically identical with spacing of $25 \mathrm{~cm} \times 25 \mathrm{~cm}$ in variety BINA dhan-10 and the lowest straw yield was recorded in BRRI dhan 28 with the interacting spacing of $40 \mathrm{~cm} \times 40 \mathrm{~cm}$ (Table 2). This result of straw yield and is at per with (Salma et al., 2017; Islam et al., 2014). They reported that highest straw yield and biological yield was obtained when variety BR 25 was cultivated with the spacing of $25 \mathrm{~cm} \times 15 \mathrm{~cm}$.

\section{CONCLUSION}

Different genotypes and different planting geometry can influence the growth and yield performance of Boro rice. Based on the present study it can be concluded that BINA dhan-10 may be grown under $25 \mathrm{~cm} \times 15 \mathrm{~cm}$ in order to get maximum grain yield for Boro rice cultivation.

\section{ACKNOWLEDGMENT}

The study was financially supported by National Science and Technology fellowship under Ministry of Science and Technology, Government of Bangladesh. Authors are grateful to teachers and staffs of Bangladesh Agricultural University for technical and logistic support.

\section{REFERENCES}

AIS. (2020). Agricultural Information Services, Department of Agricultural Extension, Bangladesh. Production and area of field crops. Pp.13.

Akando, M.A. (2007). Effect of variety and spacing on the growth, yield and yield contributing characters of aromatic rice. M.S. Thesis. Dept. of Agronomy, Bangladesh Agricultural University, Mymensingh. 
Ali, S., Ibin-i Zamir, M.S., Farid, M., Farooq, M.A., Rizwan, M. and Ahmad, R. (2016). Growth and yield response of wheat (Triticum aestivum L.) to tillage and row spacing in maize-wheat cropping system insemi-arid region. Eurasian Journal of Soil Science, 5(1): 53-61.

BBS. (2020). Bangladesh Bureau of Statistics. Yearbook of Agricultural Statistics-2019. Pp.7-34.

Bisne, R., Motiramani, N.K. and Sarawgi, A.K. (2006). Identification of high yielding hybrids in rice. Bangladesh Journal of Agricultural Research, 31(1): 171-174.

BINA. (2021). Bangladesh Institute of Nuclear Agriculture. Fertilizer recommendation for rice varieties. Retrieved September 10, 2021.

BRRI. (2021). Bangladesh Rice Research Institute. Fertilizer recommendation for rice varieties. Retrieved September 10, 2021.

Darwinkel, A., Hag, B.A. and Kuizenga, J. (1977). Effect of sowing date and seed rate on crop development and grain production of winter wheat. Netherlands Journal of Agriculture Science, 24: 83-94.

Das, T.K. and Yaduraju, N.T. (2011). Effects of missing- row sowing supplemented with row spacing and nitrogen on weed competition and growth and yield of wheat. Crop and Pasture Science, 62: 48-57.

Eissa, A.M., Shehab, T.M. and Dawood, A.M. (1995). Row spacing and seeding rate effects on yield and yield components of spring wheat in Al - Qassim Region, Saudi Arabia. Assiut Journal of Agricultural Sciences, 26: 25- 36.

Gawali, A., Puri, I.S. and Swamy, S.L. (2015). Evaluation growth and yield of wheat varieties under ceiba pentandra based agri-silviculture system. Universal Journal of Agricultural Research, 3(6): 173-181.

Gomez, K.A. and Gomez, A.A. (1984). Statistical procedure for agricultural research. John Wiley and Sons, New York.

Hussian, I., Khan, M.A. and Ahmad, K. (2003). Effect of row spacing on the grain yield and yield component of wheat (Triticum aestivum L.). Pakistan Journal of Agronomy, 2(3): 153-59.

Islam, S.S., Aktar, M.M., Amin, M.H.A., Kayess, M.O. and Alam, M.R. (2014). Performance of spacing and level of nitrogen on the yield and yield contributing characters of aromatic rice cv kalizira. Bangladesh Research Publications Journal, 9(3): 168-174.

Kabir, M.E., Kabir, M.R., Jahan, M.S. and Das, G.G. (2004). Yield performance of three aromatic fine rice in a coastal medium high land. Asian Journal of Plant Science, 3(5): 561-563.

Koireng, R.J., Devi, N.M., Devi, K.P., Gogoi, M. and Anal, P.S.R. (2019). Effect of variety and spacing on the productivity of direct seeded Rice (Oryza sativa L) under Manipur condition. Indian Journal of Pure and Applied Biosciences, 7(5): 335-341.

Kumar, A.S.P. and Ali, N. (2013). Response of Wheat (Triticum aestivum L. emend. Fori \& Paol.) Varieties to Sowing Dates. Journal of Research, 25(1): 56-59.

Mali, H. and Choudhary, J. (2011). Performance of bread wheat (Triticum aestivum L.) varieties under different row spacing. Journal of Wheat, 4(2): 55-57. 
Niu, J., Li, Y., Zhang, W., Niu, Z. and Zhou, M. (2001). High yielding and good quality Tianjin 1244.Japonica hybrid cultivar series. International Rice Research, 26(1): 12.

Nizamani, G.S., Imtiaz, A.K., Abdula, K., Siddiqui, M.A., Nizamani, M.R. and Khaskheli, M. I. (2014). Influence of different row spacing on agronomic traits in different wheat varieties. International Journal of Development Research, 4(11): 2207-2211.

Rahman, M.A., Hossain, S.J., Hossain, M.B., Ami, M.R. and Sarkar, K.K. (2010). Effect of variety and culture method on the yield and yield attributes of wheat. International Journal Sustain Crop Production, 5(3): 17-21.

Roy, T.S., Pulok, M.A.I., Rahman, M.M., Hussain, M.A. and Khatun, S. (2014). Effect of Varieties and Row Spacing on the Growth and Yield of Aus Rice. Bangladesh Research Publications Journal, 10(2): 138-144.

Salma, M.U., Salam, M.A. and Mou, M.R.J. (2017). Effect of variety and planting density on weed dynamics and yield performance of transplant Aman rice. Journal of Bangladesh Agricultural University, 15(2): 167-173.

Sihag, S.K., Singh, M.K., Meena, R.S., Naga, S.R., Bahaduri, S., Sreedhar, M. and Ganesh, M. (2010). Studies on influence of age of seedlings and spacing on seed yield and quality under system of rice (Oryza sativa L.) intensification. The Journal of Research ANGRAU, 38(1/2): 103-107.

Statista. (2019). Retrieved November 21, 2020 fromhttps://www.statista.com/statistics/ 255945/top-countries-of-destination-for-us-rice exports-2011/.

Suleiman, A.A., Nganya, J.F. and Ashraf, M.A. (2014). Effect of cultivar and sowing date on growth and yield of wheat (Triticum aestivum L.) in Khartoum, Sudan. Journal of Forest Products \& Industries, 3(4): 198-203.

Sultana, M., Kader, M.A., Islam, M.S. and Zaman, F. (2012). Performance of transplanted Aman rice under various levels and sources of nitrogen application. Bangladesh Journal of Environment Science, 23: 202-206.

Tyeb, A., Paul, S.K. and Samad, M.A. (2013). Performance of variety and spacing on the yield and yield contributing characters of transplanted aman rice. Journal of Agroforestry and Environment, 7(1): 57-60.

Yang, J., Peng, S., Wang, Z. and Zhu, Q. (2001). Source-sink characteristics of japonica/indicia hybrid rice. International Rice Research Notes, 26(2): 1. 